University of Nebraska - Lincoln

DigitalCommons@University of Nebraska - Lincoln

USDA Forest Service / UNL Faculty Publications U.S. Department of Agriculture: Forest Service -National Agroforestry Center

July 2004

\title{
Simulating the dynamics of linear forests in Great Plains agroecosystems under changing climates
}

\author{
Qinfeng Guo \\ University of Nebraska - Lincoln \\ James R. Brandle \\ University of Nebraska - Lincoln, jbrandle1@unl.edu \\ Michele M. Schoeneberger \\ University of Nebraska - Lincoln, mschoeneberger1@unl.edu \\ D. Buettner \\ USDA - National Agroforestry Center, Rocky Mountain Research Station
}

Follow this and additional works at: https://digitalcommons.unl.edu/usdafsfacpub

Part of the Forest Sciences Commons

Guo, Qinfeng; Brandle, James R.; Schoeneberger, Michele M.; and Buettner, D., "Simulating the dynamics of linear forests in Great Plains agroecosystems under changing climates" (2004). USDA Forest Service / UNL Faculty Publications. 5.

https://digitalcommons.unl.edu/usdafsfacpub/5

This Article is brought to you for free and open access by the U.S. Department of Agriculture: Forest Service -National Agroforestry Center at DigitalCommons@University of Nebraska - Lincoln. It has been accepted for inclusion in USDA Forest Service / UNL Faculty Publications by an authorized administrator of DigitalCommons@University of Nebraska - Lincoln. 


\title{
Simulating the dynamics of linear forests in Great Plains agroecosystems under changing climates
}

\author{
Qinfeng Guo, J. Brandle, M. Schoeneberger, and D. Buettner
}

\begin{abstract}
Most forest growth models are not suitable for the highly fragmented, linear (or linearly shaped) forests in the Great Plains agroecosystems (e.g., windbreaks, riparian forest buffers), where such forests are a minor but ecologically important component of the land mosaics. This study used SEEDSCAPE, a recently modified gap model designed for cultivated land mosaics in the Great Plains, to simulate the effects of climate change on the dynamics of such linear forests. We simulated the dynamics of windbreaks with different initial planting species richness and widths (light changes as the selected resulting factor) using current climate data and nested regional circuiation models (RegCMs). Results indicated that $(i)$ it took 70-80 simulation years for the linear forests to reach a steady state under both normal (present-day) and warming climates; (ii) warming climates would reduce total aboveground tree biomass and the spatial variation in biomass, but increase dominance in the linear forests, especially in the upland forests; (iii) linear forests with higher planting species richness and smaller width produced higher aboveground tree biomass per unit area; and (iv) the same species performed very differently with different climate scenarios, initial planting diversity, and forest widths. Although the model still needs further improvements (e.g., the effects of understory species should be included), the model can serve as a useful tool in modeling the succession of linear forests in human-dominated land mosaics under changing climates and may also have significant practical implications in other systems.
\end{abstract}

Résumé : La plupart des modèles de croissance ne sont pas adaptés aux forêts fortement fragmentees et linéaires (ou de forme linéaire) dans les agro-écosystèmes des Grandes Plaines ( $p$. ex., les coupe-vents ou les bandes riveraines) où de telles forêts représentent une composante mineure mais non moins écologiquement importante de la mosaique du paysage. Dans cette étude, les auteurs ont utilisé SEEDSCAPE, un modèle de trouée récemment modifié et conçu pour la mosaïque du paysage agricole, pour simuler les effets des changements climatiques sur la dynamique de telles forêts linéaires. Ils ont simule la dynamique des coupe-vents de différentes largeurs (la lumière change en conséquence) et diversités spécifiques au moment de la plantation initiale, à l'aide de données climatiques actuelles et de modèles hiérarchisés de circuiation régionale (MCRég). Les résultats ont montre (i) que l'état d'équilibre a été atteint dans les forêts linéaires après 70-80 ans de simulation, tant sous le climat normal (actuel) que sous un climat plus chaud; (ii) qu'un climat plus chaud réduirait la biomasse aérienne des arbres et sa variabilité spatiale mais augmenterait la dominance dans les forêts linéaires, plus spécifiquement dans les forêts des hautes terres; (iii) que les forêts linéaires plus étroites avec une plus grande tichesse specifique au moment de la plantation produiraient plus de biomasse ligneuse aérienne par unité de surface; et (iv) que les mêmes espèces se comportent de façon très différente selon le scénario climatique, la diversité au moment de la plantation et la largeur de la forêt. Même si le modèle requiert certaines ameliorations ( $p$. ex., l'effet des espèces du sous-bois devrait être inclus), ce dernier peut être utilisé pour modéliser la succession forestière des forêts linéaires dans des mosaïques du paysage dominé par l'homme sous des conditions climatiques changeantes et peut également avoir d'autres implications pratiques importantes dans d'autres systèmes.

[Traduit par la Rédaction]

\section{Introduction}

Human-dominated ecosystems in the Great Plains are speculated to be especially sensitive to climate changes because of their highly fragmented nature. In the Great Plains, woody areas, predominantly agroforestry plantings (such as riparian forest buffers and windbreaks, but also natural woody draws and fences and field borders) make up only a small portion of the agricultural land mosaics, yet provide many vital services. These woody areas enhance crop protection and production through their sheltering effects, provide habitats and travel corridors for plants and wildife, and protect water quality (Kort 1988; Guertin et al. 1997; Rosenberg et al. 1997; Guo 2000; Easterling et al. 2001). However, the succession and functions of these Great Plains forests under varying climates have been largely overlooked and little in-

Received 25 March 2004. Accepted 30 July 2004. Published on the NRC Research Press Web site at http://cjfr.nrc.ca on 12 January 2005.

Q. Guo, ${ }^{1,2}$ J. Brandle, and D. Buettner. School of Natural Resources, University of Nebraska, Lincoln, NE 68583-0814, USA. M. Schoeneberger. USDA - National Agroforestry Center, Rocky Mountain Research Station, East Campus, University of Nebraska, Lincoln, NE 68583-0822, USA.

${ }^{1}$ Corresponding author (e-mail: qguo@usgs.gov).

${ }^{2}$ Present address: US Geological Survey, 871137 th Street SE, Jamestown, ND 58401, USA. 
Fig. 1. A fraction of a hypothetical, spatially explicit agricultural land mosaic $\left(1 \mathrm{~km}^{2}\right)$ that contains the three major spatial components in the agricultural land mosaics of the Great Plains (wider solid, riparian zone; narrower solid, windbreak; open: crop land). Each simulated area $\left(1 \mathrm{~km}^{2}\right)$ contains ten-thousand $10 \mathrm{~m} \times 10 \mathrm{~m}$ plots.

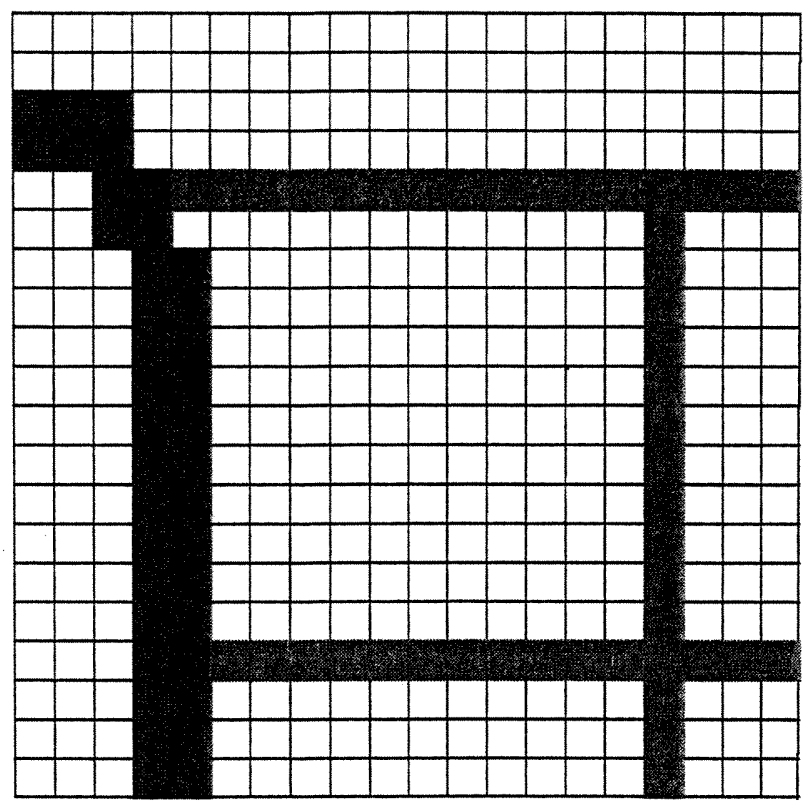

formation on temporal changes in community structure is available (Easterling et al. 2001).

Individual-based, spatially explicit gap models designed to simulate the effects of climate change on forest growth have been well developed and broadly used (e.g., Prentice et al. 1993; Liu and Ashton 1995, 1998; Guertin et al. 1997). In these models, the establishment, growth, reproduction, and death of individual trees on a small plot of land (e.g., $10 \mathrm{~m} \times 10 \mathrm{~m}$ ) are simulated. In many studies that use these models, the forest dynamics in the plots are assumed to represent the surrounding forest. Since these models were designed for contiguous upland forests, direct application to the highly fragmented, linear forests in the Great Plains presents a number of problems.

For forested regions in which a single plot is assumed to represent a large area, gap models usually include ubiquitous seed dispersal, that is, where the plot receives seeds of all species that might occur in the land mosaics (Shugart 1984). Establishment of trees depends entirely on the survival of seedlings rather than on their arrival on the plot. In reality, the location of any plot in the land mosaics will affect its probability of receiving seeds that disperse from other plots in the land mosaics. Therefore, a single plot cannot be assumed to represent the entire forest accurately (Liu and Ashton 1998; Easterling et al. 2001).

Linear forests, especially windbreaks and riparian forest buffers, result in a greater proportion of trees in the land mosaics that are on the forest's edge. Therefore, the edge effect (i.e., greater light availability) dominates in these systems in contrast to nonlinear forest stands. In addition, the Great Plains comprises a mixture of upland and riparian linear forests that experience very different water regimes. In many parts of the Great Plains, the water table in upland areas is extremely deep, and trees gain their water predominantly from precipitation. In riparian areas, water is also available from groundwater that occurs closer to the surface in the land adjacent to streams or rivers. The availability of this water fluctuates over time.

To accommodate the unique features of the growth of linear forests in agricultural land mosaics, we developed and tested a new model, SEEDSCAPE (Guertin et al. 1997; Easterling et al. 2001). Based on existing gap models, SEEDSCAPE was constructed to overcome the limitations of existing forest models and to provide a starting point for understanding ecological processes in these heavily human-dominated land mosaics. In our earlier work, we simulated the forest growth under land use changes and normal climates (Easterling et al. 2001). Possible effects of large forest edge/width ratio on light penetration into the linear forests had not yet been incorporated into the model for this earlier simulation. In the present study, we have modified our model to take such potential effects into account.

To provide better guidelines for on-the-ground management of these woody components and to better direct conservation programs that promote and provide assistance to establish new plantings, we need to understand the ecological implications of both future climate change and dimensional variation of linear forests. Warming climates are likely to alter the existing forest structure and dynamics, and linear forests with varying widths may support different biodiversity values and crop productions. Information derived from modeling efforts such as SEEDSCAPE will assist with development of design criteria (such as ideal size (length and width), spatial arrangement, and optimal density over time) that can better balance the production and conservation demands being made on these lands.

In this paper, we report our results of using SEEDSCAPE to simulate the dynamics of windbreaks having different species richness and widths and under different climatic scenarios. For this study, we asked the following questions: (i) How would global climate change affect the growth of linear forests in the Great Plains? (ii) How would planting species richness (i.e., the number of species) affect the forest growth under different climatic scenarios? (iii) How would forest width affect aboveground tree biomass and evenness?

\section{Materials and methods}

\section{The SEEDSCAPE model}

The SEEDSCAPE model is derived from a gap model, JABOWA II (Botkin et al. 1972; Botkin 1993). Details on the development and initial testing of the model are available in Easterling et al. (2001). The main features of this model are described next.

(i) Extends the single-plot approach to an entire land mosaic of multiple plots $(10 \mathrm{~m} \times 10 \mathrm{~m})$ over a $100 \times 100$ grid ( $1 \mathrm{~km}^{2} ; \mathrm{Fig} .1$ ). This feature can incorporate the fundamental differences between forest stands with small edge/area ratios (e.g., large forested tracts) and ones with large edge/area ratios (e.g., riparian forest buffers). In addition, because the $1-\mathrm{km}^{2}$ land mosaic is not a closed system, plots along the edges of the mosaic can be designated as seed sources. These plots contain spe- 
Table 1. Values of $\varphi$ for each dispersal agent used in dispersal equation.

\begin{tabular}{llr}
\hline Dispersal agent & $i$ & $\varphi$ \\
\hline Wind (short distance) & 1 & 1.07 \\
Wind (intermediate) & 2 & 1.04 \\
Wind (intermediate) & 3 & 1.01 \\
Wind (long distance) & 4 & 0.90 \\
Mammal & 5 & 1.02 \\
Bird (blue jay) & 6 & 0.94 \\
Bird (other) & 7 & 0.99 \\
Gravity & 8 & 10000.00 \\
\hline
\end{tabular}

Note: Dispersal agents are based on Malanson and Armstrong (1996) (revised from Easterling et al. 2001).

cies that are found outside the $1-\mathrm{km}^{2}$ area, but are close enough to deliver seeds to the entire mosaic. Within this mosaic, each plot is assigned particular values for soil type, initial vegetation, and location (i.e., whether the plot is in a riparian or upland area). The soil type determines moisture capacity, available nitrogen in the soil, soil depth, and the depth to the water table. The species and diameter at breast height (DBH) of all trees in each wooded plot are assigned at the start of the model run.

(ii) Allows seed dispersal among all plots in the simulated land mosaics. This feature links the entire array of species that occur in a given area, connecting all simulated plots. SEEDSCAPE uses the dispersal algorithm from the SEEDFLO model (Hanson et al. 1990). In this algorithm, each plot is used as a potential seed source if it contains trees large enough to produce seed and if those trees actually produce seeds in a given year as determined by the species-specific probability of seed production. Each species can have up to three dispersal mechanisms within a total of eight dispersal categories (Table 1). Initially, each tree's age is set to the minimum age for seed production (though some are explicitly set to another age). For each tree in each plot, the probability of seeds reaching each of the other potentially wooded plots in the mosaics is determined by the simple distance-decay function, $P_{i j}=d_{j}^{-\Phi} i$, where $i$ is a speciesspecific dispersal agent, $P_{i j}$ is the probability of a seed dispersing to plot $j$ given a dispersal agent $i, d_{j}$ is the distance in metres to plot $j$, and $\varphi_{i}$ is the dispersal parameter for a dispersal agent $i$ (Okubo and Levin 1989). Once seeds have arrived on a plot, the seedling establishment, growth, and mortality functions are similar to those in other existing gap models. The specific equations in SEEDSCAPE are the same as those in JABOWA-II (Botkin 1993).

(iii) Allows locally variable water tables. For upland plots, the availability of water is the same as in JABOWA-II and is determined by precipitation and by depth to the water table. Because the water table in our study area is extremely deep in upland locations, it is not a major factor influencing tree growth. In riparian plots, however, the soil may be completely saturated because of a shallow water table, the result of flooding along watercourses after precipitation events. SEEDSCAPE therefore allows for variable local water tables in riparian plots. The water table varies with water volume in the streams, which is in turn a function of runoff from surrounding agricultural fields. SEEDSCAPE uses the curve number method developed by the USDA - Natural Resources and Conservation Services (USDA - NRCS 1972) to calculate runoff volume following precipitation events.

(iv) Incorporates edge effects. Forest width greatly affects the levels of light penetration in the simulated plots. Light levels for each plot change according to the number of neighboring plots surrounding the focal plot. Each plot has the possibility of having two, three, or four neighboring plots, depending on the planted forest width. For a single plot without any neighbors, assuming the light level on the south-facing edge to be one, light levels on the east-, west-, and north-facing edges will be calculated as $0.5,0.5$, and 0.25 . However, if a plot has a neighbor, the light level at the edge that connects to the neighbor plot will be designated as zero. Although we do not have field measurement data on light levels, we believe that such assumptions are sufficient and reasonable for the purpose of showing the light effects on the forest edges in the Great Plains region.

We used vegetation reference data from Easterling et al. (2001), which included the number of stems of each tree species and DBH for 10 species found in both riparian zones and windbreaks in $1-\mathrm{km}^{2}$ land mosaics of Mead, Saunders County, Nebraska (Table 2). The data were based on a survey made of the surrounding area to estimate the number and DBH of the potential seed source trees in 1995 (for details regarding the field data collection, see Easterling et al. 2001).

Ten iterations of a 400-year simulation for both windbreaks and riparian zones with three different forest widths $(10,20$, and $30 \mathrm{~m})$ were simulated under both current (hereafter referred to as "normal") climatic conditions and climatic change scenarios. For simulations under normal climate, we used monthly weather data for 1967-1995 from the nearest weather station (located near Mead, Nebraska). For simulations under warming climate, we used a second-generation regional climate model (RegCM2), which is a nested regional climate model developed by the National Center for Atmospheric Research (NCAR) for the MINK region (Missouri, Iowa, Nebraska, Kansas). In the warming scenario, seasonal near-surface warming of $4-6 \mathrm{~K}$ (or $4-6{ }^{\circ} \mathrm{C}$ ) and seasonal precipitation increases of $6 \%-24 \%$ were simulated for doubled atmospheric carbon dioxide concentration ( $2 \times$ $\mathrm{CO}_{2}$ ) conditions.

The NCAR second-generation RegCMs are driven by outputs from control and equilibrium $2 \times \mathrm{CO}_{2}$ simulations produced by the general circulation model (GCM) of the Australian Commonwealth Scientific and Industrial Research Organization (CSIRO) described by Watterson et al. (1995). RegCMs include improved formulations of boundary layer, radiative transfer, surface physics, cumulus convection, and time integration technique; and they model numerous climate variables such as monthly maximum $\left(T_{\max }\right)$, minimum $\left(T_{\min }\right)$, and mean temperature $\left(\left(T_{\max }+T_{\min }\right) / 2\right)$, precipitation, relative humidity $(\mathrm{RH})$, wind, and cloudiness (for details about this model, see Giorgi et al. 1993a, 1993b, 1998). The 5-yearlong normal (present-day) and $2 \times \mathrm{CO}_{2}$ simulations using 
Table 2. Reproductive parameters and dispersal agents of the species in a Nebraska forest corridor (modified from Easterling et al. 2001).

\begin{tabular}{lrrrrrrr}
\hline & & & & & \multicolumn{2}{c}{ Dispersal agent } \\
\cline { 5 - 7 } Species & SAP & Age $_{\min }$ & Age $_{\max }$ & $P_{\text {(seds) }}$ & Primary & Secondary \\
\hline Acer negundo & 3 & 30 & 100 & 1.0 & 1 & \\
Celtis occidentalis & 3 & 35 & 200 & 0.8 & 5 & 7 \\
Fraxinus pennsylvanica & 10 & 15 & 150 & 0.8 & 2 & 8 \\
Juniperus virginiana & 3 & 10 & 150 & 0.8 & 6 & \\
Morus alba & 3 & 5 & 125 & 1.0 & 6 & \\
Populus deltoides & 10 & 25 & 150 & 0.9 & 4 & 7 \\
Prunus americana & 60 & 10 & 40 & 1.0 & 5 & 7 \\
Salix amygdaloides & 10 & 10 & 85 & 0.9 & 4 & \\
Ulmus pumila & 15 & 15 & 70 & 0.5 & 2 & \\
Ulmus rubra & 3 & 15 & 200 & 0.5 & 2 & \\
\hline
\end{tabular}

Note: Dispersal agents are based on Malanson and Armstrong (1996). SAP, the maximum number of saplings added per year; age $e_{\min }$ and age ${ }_{\max }$, the minimum and maximum ages at which a tree can produce seeds; $P_{\text {(seeds): }}$ the probability that a tree will produce seeds in a given year.

Table 3. Summary of the major physical and biotic variables used in the simulation.

\begin{tabular}{|c|c|}
\hline Variable & Description \\
\hline $\begin{array}{l}\text { Climate (the whole simulated land } \\
\text { mosaic, } 1 \mathrm{~km}^{2} \text { ) }\end{array}$ & $\begin{array}{l}\text { Monthly temperature (maximum, minimum, mean, and total), precipitation, radiation, relative } \\
\text { humidity (RH), wind, light, and } \mathrm{CO}_{2} \text { level; for each grid, the weather data were corrected } \\
\text { to its specific elevation and latitude }\end{array}$ \\
\hline $\begin{array}{l}\text { Soil (each grid, } 10 \mathrm{~m} \times 10 \mathrm{~m} \text {; total, } \\
100 \times 100 \text { grid, each cell }=1 \mathrm{~km}^{2} \text { ) }\end{array}$ & Soil type, depth, water content, \% rock, nitrogen, water balance \\
\hline Vegetation & Crop land, riparian, or upland forest \\
\hline
\end{tabular}

RegCM was completed at a horizontal grid-point spacing of $50 \mathrm{~km}$ (Giorgi et al. 1998).

We chose RegCM for our simulation because it produced better normal (or present-day) climatological conditions over the central United States than other available GCM models (Giorgi et al. 1998). In our simulation, values of all the climate variables listed above for each month (January-December) were modified using the local elevation and latitude in each grid point for all grid points within the focal land mosaic, plus the corresponding observed monthly climatological data (1969-1992) from the Mead Weather Station. The forests were initialized to have trees of the component species with minimum ages of seed production at the start of the simulation. Soil data used in the model came from a Saunders County soil survey (USDA - NRCS, unpublished data). A brief summary of the major physical and biological variables used in the simulations is presented in Table 3.

We made cross-comparisons in forest dynamics $(i)$ under present-day climatic conditions and projected global warming scenarios; (ii) with different forest widths (i.e., 10, 20, $30 \mathrm{~m}$ ); and (iii) between a species-rich community (10 spp.) and a less diverse community (4 spp.; randomly chosen from the original pool of 10 species). We also simulated the population dynamics of each individual species under these different conditions.
Finally, we compared our simulation results with field inventory data collected from the same study site but with different windbreaks at Mead, Nebraska (M. Schoeneberger, R. Straight, J. Brandle, and X.H. Zhou, unpublished data). Validation of the simulation results using either the SEEDSCAPE model with a realistic test or direct comparisons between our simulation results and the field data was not possible at this stage for several reasons. First, long-term biomass data of the linear forests in the Great Plains are mostly unavailable, especially for each individual species. Second, the linear forests in the Great Plains are only 20-100 years old and the forest at our field site is only about 20-30 years old (Easterling et al. 2001). By contrast, our simulations are much longer (i.e., 400 years). This meant that no time-series field data were comparable with our simulation results. Third, we were simulating the dynamics of forest with two fixed initial diversity categories across the entire land mosaic (i.e., 10 and 4 species), while the actual numbers of species in the field linear forests are quite different over space (i.e., from plot to plot). And fourth, the biomass of a particular species can be very different when it is planted with different numbers of species or in species assemblages (i.e., some species are present in our simulation but not in the field, and vice versa). The field windbreaks included three fast-growing tree species (Juniperus virginiana, Pinus nigra, and Fraxinus pennsylvannica) and 
Fig. 2. Temporal variation of aboveground tree biomass in the simulated forests with 10 and 4 species under both normal and projected warming climates (forest width $=10 \mathrm{~m}$ ). Vertical bars indicate the spatial variation (SE) of aboveground biomass among simulated plots (paired Student's $t$ tests on SE of tree biomass across plots, $P<0.0001)$.

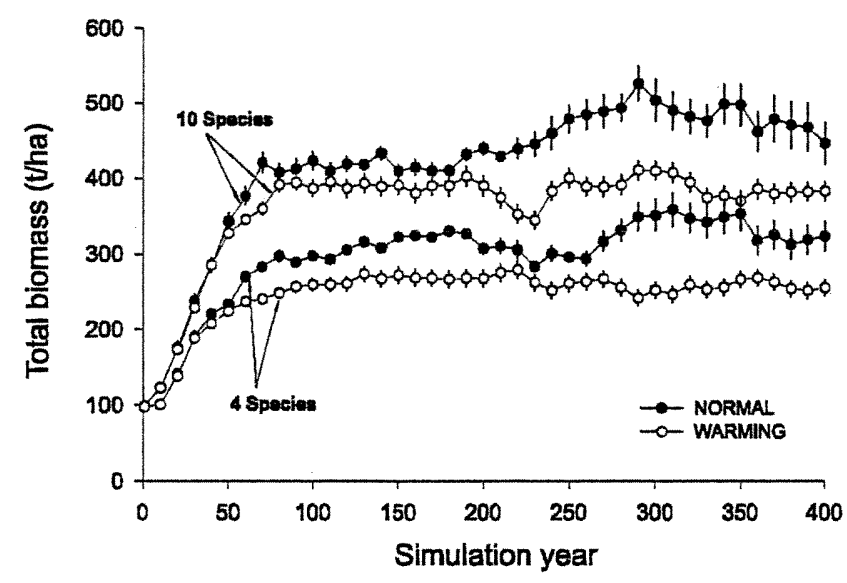

one (Pinus nigra) that was not present in our simulation. For these reasons, we did not attempt to compare individual species' performance in the simulation and in the field.

\section{Simulation results}

Our modeling results showed that it took at least $70-80$ simulation years for both riparian zones and windbreaks to reach a steady state under current climatic conditions and under climatic warming. After that period, aboveground tree biomass and species composition were relatively constant over the other 320 simulation years.

\section{Effects of climatic warming}

Given a certain level of species richness or width, the linear forests produced significantly lower aboveground biomass under warming climatic scenarios than under current climatic conditions (Fig. 2; paired Student's $t$ tests, $\mathrm{df}=40$, $P<0.0001$ in all cases with different species richness levels and widths). This trend was especially apparent in planted windbreaks (data not shown). Projected climatic warming caused smaller spatial variation in tree biomass among simulated plots after 250 years (Fig. 2), but higher dominance in the forests (Fig. 3; paired Student's $t$ tests on the coefficient of variation (CV) of biomass across species over the 400 simulation years, $t=4.60$, df $=40, P<0.0001$, and $t=3.13$, $\mathrm{df}=40, P=0.003$, for 10 and 4 species forests, respectively). However, for both species richness levels (10 or 4 species) there was a short period early in succession in which $\mathrm{CV}$ values were higher under normal climates than under climatic warming (Fig. 3).

\section{Effects of species richness}

The linear forests with higher species richness did produce higher aboveground biomass under both normal (current) and projected warming climates (Fig. 2; paired Student's $t$ tests, $\mathrm{df}=40, P<0.0001$ in all cases). However, there was no clear evidence that higher species richness could lead to
Fig. 3. Community dominance measured by coefficient of variation (CV) among species under normal and projected warming climates (forest width $=10 \mathrm{~m}$ ).

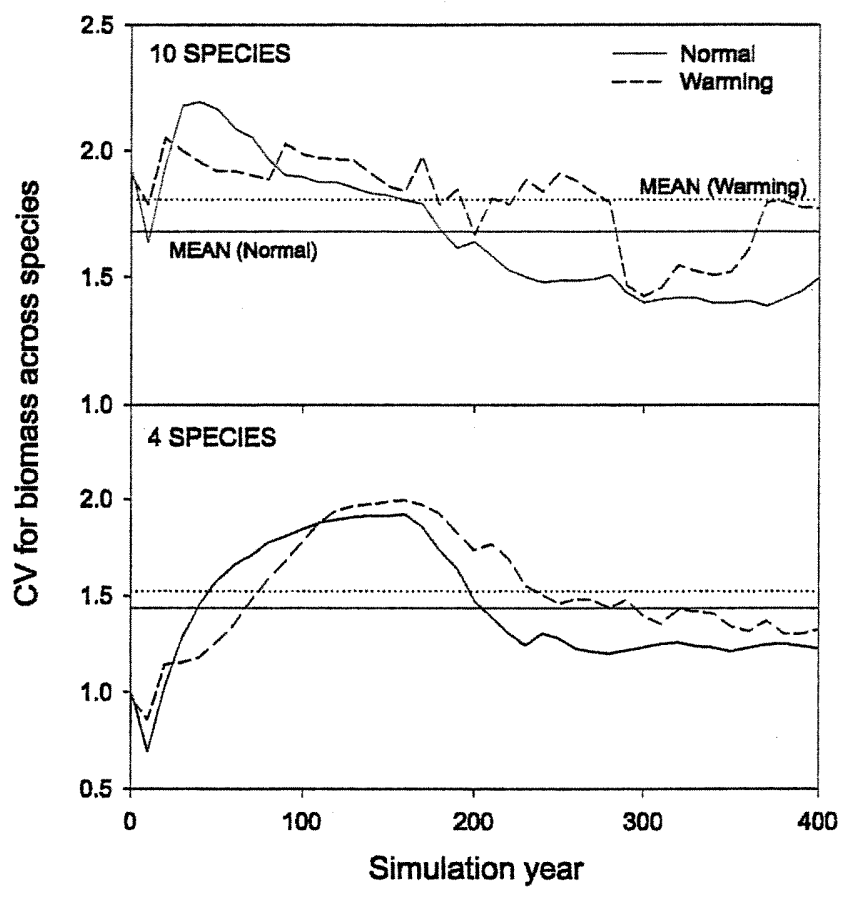

lower spatial (among simulated plots) and temporal (among simulated years) variation in tree biomass. Simulations on other random combinations of any 4 species drawn from the species pool (10 species) produced similar results (data not shown). In the forest with 10 species, the CV for biomass across species increased in the first 30-40 simulation years and then gradually declined. In the forest with four species, the CV peaked after 120 years and then declined (Fig. 3).

\section{Effects of forest width}

When total forested area and species composition were kept constant, narrower forests produced higher aboveground biomass than wider forests (Fig. 4; paired Student's $t$ tests, df $=40, P<0.0001$ ), but the spatial variation in biomass across simulated plots was smaller in wider forests than in narrower forests (Student's $t$ test on standard deviation of biomass among plots; $P<0.001$ ). Similar to the findings shown in Fig. 2, when forest width was the same, forests under normal climates or with higher species richness produced higher biomass (data not shown). We did not see any evidence that forest width affected community evenness (paired Student's $t$ test, $\mathrm{df}=40, P>0.05$ ). Forest width did not show any effects on the performance of individual species. Although the trajectory of each species was somehow different in narrower $(10 \mathrm{~m})$ and wider forests $(20 \mathrm{~m})$, there was no significant difference in the relative importance of each species measured by biomass (data not shown). Among the forests with different widths, forests with higher species richness (10 species) showed great differences in biomass than those with only 4 species.

Another notable change was the difference in the switches of species dominance when the forests were designed with 
Fig. 4. Effects of forest width $(10,20,30 \mathrm{~m})$ on aboveground tree biomass in the simulated forests with 10 species, under normal climate conditions. Vertical bars indicate the spatial variation (SE) of biomass among simulated plots. The forests with 4 species showed the same patten with width, except the aboveground biomass was lower than the forests with 10 species under each width category (data not shown) (see also Fig. 2).

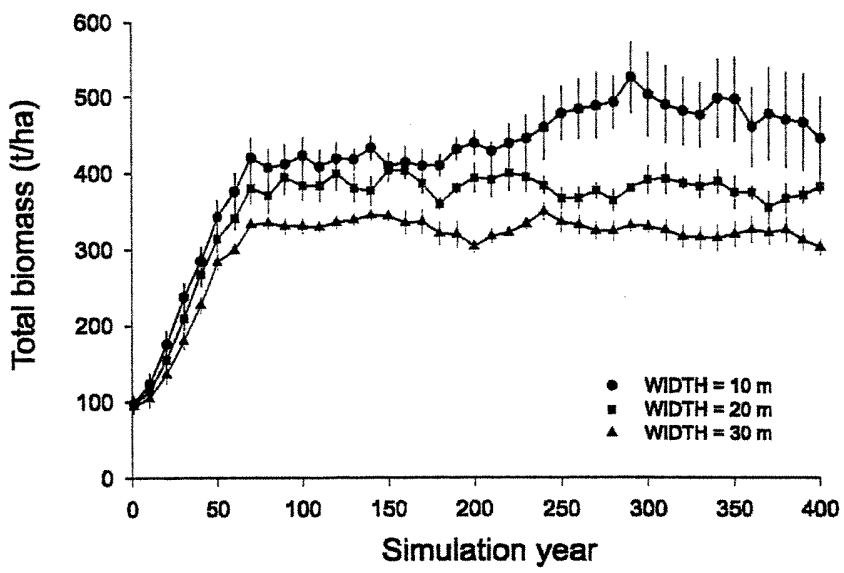

different widths, even though the forest species composition remained unchanged (data not shown).

\section{Responses of individual species}

For the 10 species planting, under normal climate simulations, Populus deltoides increased dramatically in the first 70-80 years, then its dominance was replaced by Prunus americana around year 100. Following the decline of Populus deltoides, biomass of Acer negundo and Fraxinus pennsylvanica also increased. Ulmus rubra and Celtis occidentalis showed a dramatic decline following the dramatic increase of the first two dominant species (i.e., Populus deltoides, Prunus americana) and were almost totally eliminated from the local community around year 70 and 150 , respectively. Under warming climate simulations, Populus deltoides also increased dramatically in the first 70-80 years but its dominance was gradually replaced by $F$. pennsylvanica around year 170 . Prunus americana first increased with Populus deltoides up to 40 years, then declined quite rapidly. Celtis occidentalis showed sharp decline following the dramatic increase of Populus deltoides and Prunus americana and was almost totally eliminated from the local community around year 20 (Fig. 5).

In the windbreak with 4 species, Populus deltoides and Prunus americana were the two dominant species under both normal and warming climates. However, the latter showed a unique pattern in that it first increased up to year 30 , before declining until around year 80 , when it recovered. Under normal climate simulations, Morus alba declined following the dramatic growth of the two dominant species, Populus deltoides and Prunus americana, around year 70 , and then it maintained a relatively stable population. Celtis occidentalis was low in biomass but relatively stable throughout the 400 simulation years. Under a warming climate, however, $M$. alba showed a sharp decline in the first 20 years while Celtis occidentalis did not appear (Fig. 6).
Fig. 5. Temporal variation of aboveground biomass of individual species in the simulated forests with 10 species, under both normal and projected warming climates (forest width $=10 \mathrm{~m}$ ).

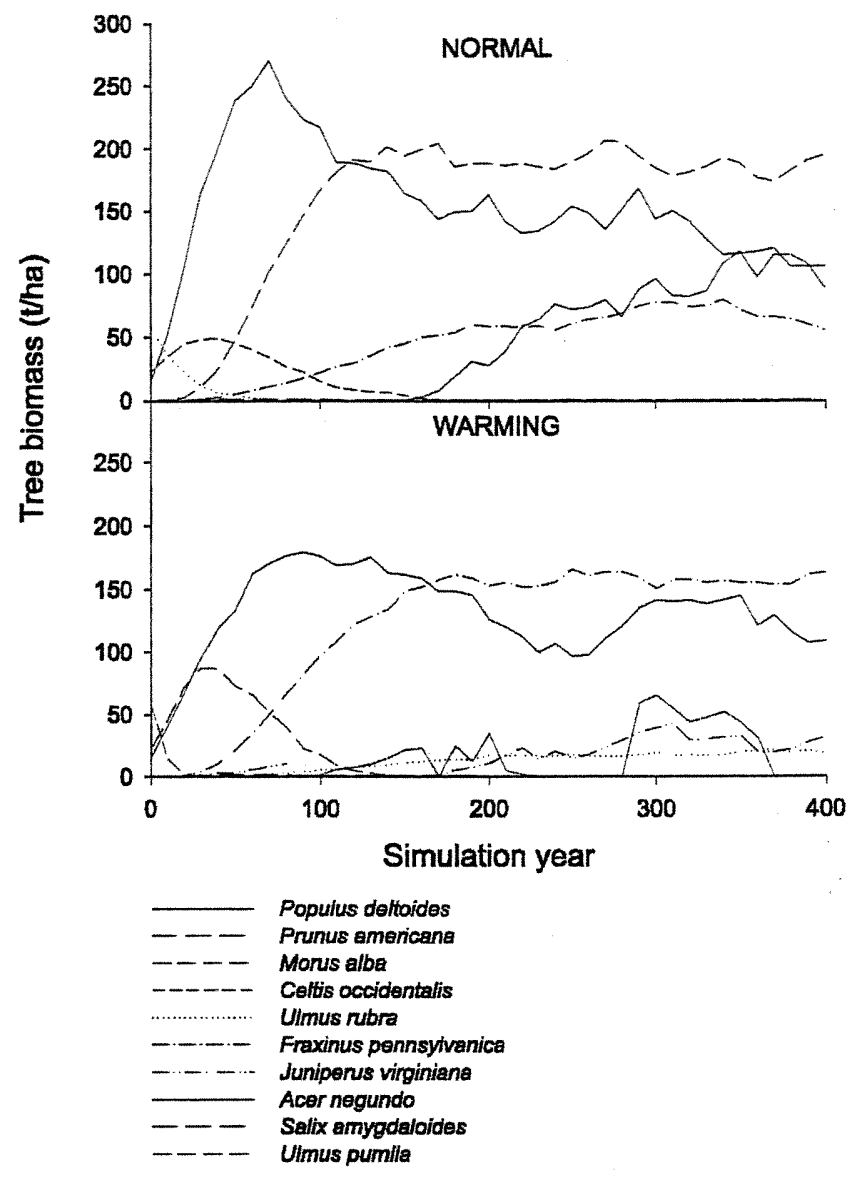

\section{Comparison with inventory data}

Because of the limitations mentioned earlier, we could not compare individual species' performance between our simulation and field data. However, using 50 years of field inventory data collected from the same site, but different windbreaks with varying species diversity and composition, we found some similarities and differences in the curves of biomass accumulation over time. Although the overall shapes of the biomass curves were similar, our simulation showed a slower rate of biomass accumulation over time (especially in the forest with a four-species planting) than was evident in field observations. In year 50 , the forest with 10 species produced higher biomass (approx. 35-40 t/ha) than the field windbreak, while the one with 4 species produced lower biomass (approx. 60-65 tha). Also, the increase of biomass in the simulation was more gradual, although there was a larger jump between $20-30$ years in the field (Fig. 7).

\section{Discussion}

Although various forest growth models have been developed and applied to study the effects of climate change on ecosystems (e.g., Solomon 1986; Shugart et al. 1992; Prentice et al. 1993; Bugmann 1996), a suitable model that could ad- 
Fig. 6. Temporal variation in aboveground biomass of individual species in the simulated forests with four species, under both normal and projected warming climates (forest width $=10 \mathrm{~m}$ ).
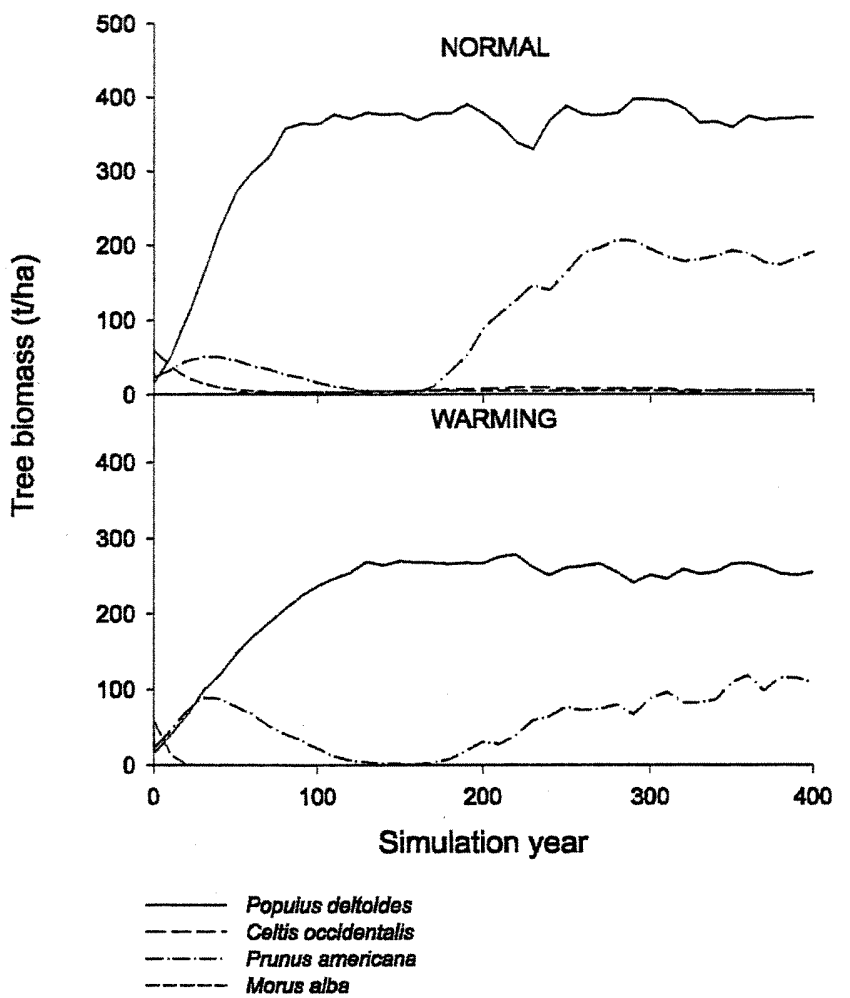

equately address the highly fragmented linear-shaped forests in the Great Plains has only recently become available (Easterling et al. 2001). The modified forest gap model, SEEDSCAPE, is the first example of using a spatially explicit, individualbased forest gap model to simulate successional processes in the linear forest types (riparian zones and windbreaks) of the Great Plains.

This study, using the latest version of SEEDSCAPE that takes light effects into better account, is a further successful development. Our simulation results indicate that the model could identify the effects of climatic warming, differential initial species richness, forest width, and enhanced light levels (because of the highly fragmented linear nature of the forests) on the forests of the Great Plains agricultural ecosystems. The model also clearly revealed the shifts in species dominance under different climatic scenarios over time and the highly individualistic responses of the different species. The simulated successional trends in total aboveground biomass after planting with different initial species richness and forest widths and under both current and projected climates are very similar to commonly observed patterns in many other systems (Guo 2003).

\section{Effects of climatic warming}

Using different RegCM models to examine the effects of global climate change would certainly produce different results. Our study using RegCM2 (Giorgi et al. 1998) suggests that lower biomass and community evenness would be produced under warming climates regardless of the original spe-
Fig. 7. Comparison between our simulation results and field inventory data from the same study site but with different windbreaks and different species composition and richness.

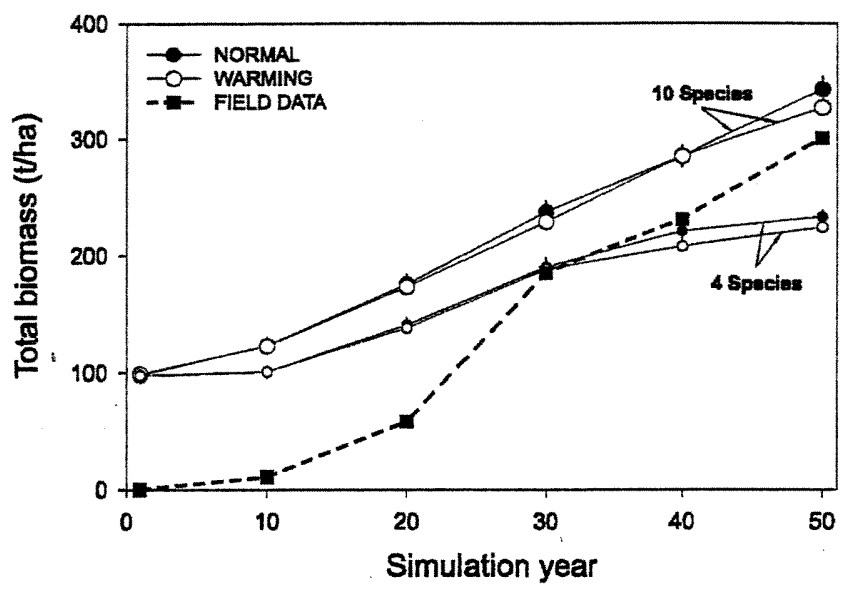

cies richness and forest shape (e.g., width). The RegCMs have proven to be useful tools to examine the effects of climate change, especially in agroecosystems because of their relatively high spatial resolution relative to other climate and agricultural models (Giorgi et al. 1998). However, it is not yet clear from our model structure why spatial variation (standard deviation) in biomass across simulated plots became greater after 225 simulation years in linear forests with 10 species under both a normal climate and a warming climate (Figs. 2, 4).

\section{Effects of species richness}

Our simulation results support those from earlier studies that demonstrated a species-richer community would produce higher aboveground biomass and community evenness than a community lacking such richness (e.g., Lehman and Tilman 2000). However, in contrast to the findings in several recent studies (e.g., McCann 2000), we failed to identify a clear relationship between initial species richness and community stability (measured as CVs on biomass over time) in our simulation results.

\section{Effects of forest width}

Edge effect on forest growth is complex because it includes light, wind, humidity, snow deposition, eolian sediment, and seeds. Here we simply examine how forest width affects the growth of linear forest, by changing the proportion of edge in the forest and therefore the level of light. Our simulation results suggest that forest corridor width in the Great Plains agroecosystems will have a significant effect on the successional characteristics of those linear forests. However, this effect will be greatly reduced when the linear forests become considerably wide (i.e., when the edge area is only a small portion of the total forest area). In our simulation, when the forest width is much greater than $30 \mathrm{~m}$, the edges do not impose much effect on the forest growth. The greater amount of light reaching the ground at the forest edge can stimulate germination of many understory species so that they can coexist with overstory species, leading to higher species richness and higher biomass (Kupfer and Malanson 1993; Matlack 1994). There is no evidence from 
our simulation that wider corridors support higher plant community evenness. However, the reason for this may be that the model structure currently does not simulate all species that can potentially occur in these systems, which is a definite weakness of the SEEDSCAPE model.

The greater than expected effect of light penetration on the growth of linear forests was contrary to earlier reports regarding width effects (Easterling et al. 2001). Such effects of edge increase significantly as forest width decreases and the ratio of edge/interior area increases. Conversely, as the forest width increases, the relative proportion of the forest edge area will become smaller and the light and other edge effects should correspondingly decline.

\section{Responses of individual species}

The growth trajectories and responses of species under the same climate regime (normal vs. warming) were clearly highly individualistic, and even the same species performed differently under different climate conditions or when it was planted with different species (e.g., Populus deltoides). (Figs. 5, 6). Given the range of physiological characteristics in the species we used in our simulations, individualistic responses of the species to both normal climatic fluctuation and climatic warming were expected. We do not have enough data to determine why some species showed more dramatic responses or fluctuations than others. However, such information will be critical for selecting the more adaptive species for future windbreak planting (Huston and Smith 1987).

\section{Testing with inventory data}

Validation of the long-term simulation results with realistic testing was not unfeasible. Using 50 years of inventory data, we found some similarities and differences in the curves of forest biomass accumulation over time. The smaller rate of biomass increase with time in our simulation could be the result of to several factors. First, our simulation started with trees of minimum seed production ages, while the first field observation was made 10 years after planting (assuming no tree was present at the beginning). Second, the species composition and richness in the field windbreaks were quite different from our simulation. Our simulation contained 10 or 4 species, but the field windbreaks contained only 3 species (including one, Pinus nigra, never presented in our simulation).

\section{Limitations and future improvements}

Several components in the SEEDSCAPE model need further development. Feedback between trees and the environment bas not yet been incorporated into the model; forest growth itself will modify the local and regional environments (Chen et al. 1999). For example, the reduced aboveground tree biomass under projected future warming climates (doubled $\mathrm{CO}_{2}$ concentration) will likely impact future forest environments detrimentally by reducing the ecosystem carbon storage capacity. Furthermore, the present model only includes trees and dominant shrubs and does not fully consider all understory species. This constraint will be more difficult to address because of the great expense in terms of computing time and space and the lack of empirical data. Ideally, all component species in different plant life forms (i.e., shrubs and herb species) should be included in the modeling efforts. One means of accomplishing this would be to use a design of smaller patches for shrubs and herbaceous plants nested within the original large patches for trees.

Wooded corridors are expected to expand throughout much of the Great Plains as a result of planting, suppression of wildfire (Knight et al. 1994), and reduced river flows in some riparian areas (Johnson 1994). After new windbreaks are planted, understory species are likely to invade from nearby riparian forest zones (species pool). Future revisions of the model will need to focus on the potential effects of this forest expansion over time and the effect of the spatial arrangements (e.g., connectivity or proximity) of riparian zones relative to windbreaks across the agricultural land mosaics to the regional level. Some limitations (e.g., light effects) stated in Easterling et al. (2001) have been addressed in this simulation effort. However, additional work such as sensitivity analysis on the reciprocal effects of moisture, temperature, wind, and related biological factors in the model are needed for further improvements.

In summary, SEEDSCAPE is a tool to improve our understanding of forest succession in Great Plains agroecosystems. The ultimate goal is to assist ecosystem management in terms of species selection and spatial forest arrangements so that plantings can better meet biodiversity conservation and crop production objectives under current and projected climatic scenarios (Easterling 1996). The simulation results show that the structure and dynamics in the linear forests (riparian zones and windbreaks) were significantly different under different climatic conditions. Forest design (i.e., planting species richness and width) and management practices can significantly affect future forest structure and dynamics (Burke et al. 1991; Liu and Ashton 1995; Guo 2000). This modified model presents a good example of using spatially explicit, individual-based forest gap models to simulate the largely fragmented linear forest types in the region. It shows promise in various applications and will serve as a valuable starting point for modeling biological diversity and forest succession in human-dominated land mosaics of the Great Plains.

\section{Acknowledgments}

We thank W. Easterling for helpful communications, D. Guertin and C. Hays for assisting the earlier development of the model or field survey, and X.H. Zhou for providing the field windbreak inventory data. This research was supported by grants from the US Deparument of Energy (DOE) National Institute for Global Environmental Change (NIGEC), through the NIGEC Great Plains Regional Center at the University of Nebraska-Lincoln (DOE Cooperative Agreement No. DE-FC03-09ER61010) and USDA Forest Service Interior West Global Change Program and USDA National Agroforestry Center, both part of the USDA Forest Service, Rocky Mountain Research Station. University of Nebraska-Lincoln Agricultural Research Division Journal Series No. 14696.

\section{References}

Botkin, D.B. 1993. Forest dynamics: an ecological model. Oxford University Press, New York. 
Botkin, D.B., Janak, J.F., and Wallis, J.R. 1972. Some ecological consequences of a computer model of forest growth. J. Ecol. 60 : 849-872.

Bugmann, H.K.M. 1996. A simplified forest model to study species composition along climate gradients. Ecology, 77: 20552074.

Burke, I.C., Kittel, T.G., Lauenroth, W.K., Snook, P., Yonker, C.M., and Parton, W.J. 1991. Regional analysis of the central Great Plains. Bioscience, 41: 685-692.

Chen, J., Saunders, S.C., Crow, T.R., Naiman, R.J., Brosofske, K.D., Mroz, G.D., Brookshire, B.L., and Franklin, J.F. 1999. Microclimate in forest ecosystem and landscape ecology. Bioscience, 49: 288-297.

Easterling, W.E. 1996. Adapting North American agriculture to climate change in review. Agric. For. Meteorol. 80: 1-53.

Easterling, W.E., Brandle, J.R., Hays, C.J., Guo, Q., and Guertin, D.S. 2001. Simulating the impact of human land use change on forest composition in the Great Plains agroecosystems with the SEEDSCAPE model. Ecol. Model. 140: 163-176.

Giorgi, F., Marinucci, M.R., and Bates, G.T. 1993a. Development of a second-generation regional climate model (RegCM2). Part I: boundary-layer and radiative transfer processes. Mon. Weath. Rev. 121: 2794-2813.

Giorgi, F., Marinucci, M.R., De Canio, G., and Bates, G.T. $1993 b$. Development of a second-generation regional climate model (RegCM2). Part II: convective processes and assimilation of lateral boundary condition. Mon. Weath. Rev. 121: 2814-2832.

Giorgi, F., Mearns, L., Shields, S., and McDaniel, L. 1998. Regional nested model simulations of present day and $2 \times \mathrm{CO}_{2}$ climate over the central Great Plains of the U.S. Clim. Change, 40: 457-493.

Guertin, D.S., Easterling, W.E., and Brandle, J.R. 1997. Climate change and forests in the Great Plains. Bioscience, 47: 287-295.

Guo, Q. 2000. Climate change and biodiversity conservation in Great Plains agroecosystems. Global Environ. Change, 10: $289-$ 298.

Guo, Q. 2003. Temporal species richness-biomass relationships along successional gradients. J. Veg. Sci. 14: 121-128.

Hanson, J.S., Malanson, G.P., and Armstrong, M.P. 1990. Landscape fragmentation and dispersal in a model of riparian forest dynamics. Ecol. Model. 49: 277-296.

Huston, M., and Smith, T. 1987. Plant succession: life history and competition. Am. Nat. 130: 168-198.

Johnson, W.C. 1994. Woodland expansion in the Platte River, Nebraska: patterns and causes. Ecol. Monogr. 64: 45-84.

Knight, C.L., Briggs, I.M., and Nellis, M.D. 1994. Expansion of gallery forest on Konza Prairie Research Natural Area, Kansas, USA. Landsc. Ecol. 9: 117-125.
Kort, J. 1988. Benefits of windbreaks to field and forage crops. Agric. Ecosyst. Environ. 22-23: 165-190.

Kupfer, I.A.S., and Malanson. G.P. 1993. Structure and composition of a riparian forest edge. Phys. Geogr. 14: 154-170.

Lehman, C.L., and Tilman, D. 2000. Biodiversity, stability, and productivity in competitive communities. Am. Nat. 156: 534-552.

Liu, J., and Ashton, P.S. 1995. Individual-based simulation models for forest succession and management. For. Ecol. Manage. 75: 157-175.

Liu, J., and Ashton, P.S. 1998. FORMOSAIC: an individual-based spatially explicit model for simulating forest dynamics in landscape mosaics. Ecol. Model. 106: 177-200.

McC.ann, K.S. 2000. The diversity-stability debate. Nature (Lond.), 405: $228-233$.

Malanson, G.P., and Armstrong. M.P. 1996. Dispersal probability and forest diversity in a fragmented landscape. Ecol. Model. 87: 91-102.

Matlack. G.R. 1994. Vegetation dynamics of the forest edge trends in space and successional time. J. Ecol. 82: 113-123.

Okubo, A., and Levin, R.B. 1989. A theoretical framework for data analysis of wind dispersal of seeds and pollen. Ecology, 70: $329-338$.

Prentice, I.C., Sykes, M.T., and Cramer, W. 1993. A simulation model for the transient effects of climate change on forest landscapes. Ecol. Model. 65: 51-70.

Rosenberg, D.K., Noon, B.R., and Meslow, E.C. 1997. Biological corridors: form, function, and efficacy. Bioscience, 47: 677-687.

Shugart, H.H. 1984. A theory of forest dynamics. Springer-Verlag, New York.

Shugart, H.H., Smith, T.M., and Post, W.M. 1992. The potential for application of individual-based simulation models for assessing the effects of global change. Annu. Rev. Ecol. Syst. 23: 1538.

Solomon, A.M. 1986. Transient response of forests to $\mathrm{CO}_{2}$-induced climate change: simulation modeling experiments in eastern North America. Oecologia, 68: 567-579.

USDA - NRCS. 1972. National Engineering Handbook, Hydrology. Section 4. USDA, Soil Conservation Service, Washington, D.C.

Watterson, I.G., Dix, M.R., Gordon, H.B., and McGregor, J.L. 1995. The CSIRO nine-level atmospheric general circulation model and its equilibrium present and doubled $\mathrm{CO}_{2}$ climates. Aust. Meteorol. Mag. 44: 111-125. 